
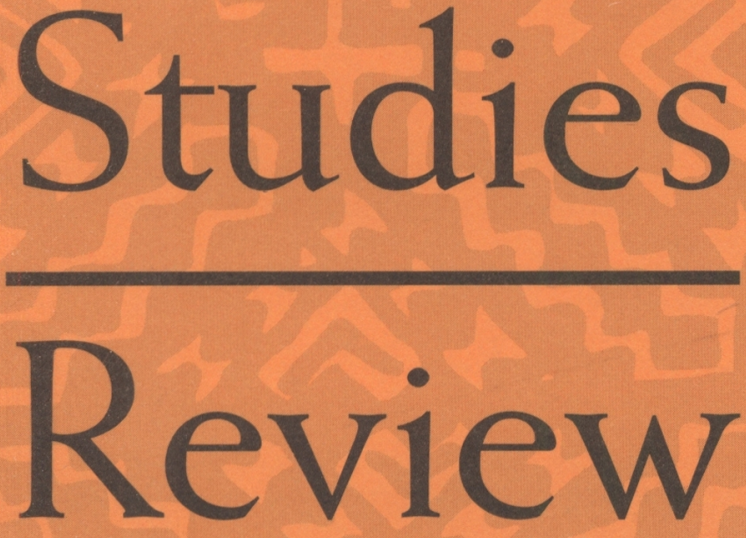

PUBLISHED BY THE AFRICAN STUDIES ASSOCIATION
Kristen E. Cheney

Identity, Migration, and

Development in the Lives of Ugandan Child Citizens

Jo Ellen Fair

The Creation of Valentine's Day in Accra, Ghana

John C. McCall

Vigilantes in Nigerian Popular Videos

\section{Ayo Olukoyun}

Media Accountability and

Democracy in Nigeria, 1999-2003

\section{Scott M. Youngstedt}

The Everyday Worlds of Hausa Migrants in Niamey, Niger

Catherine Higgs

African Women's Self-Help Organizations in South Africa, 1927-1998

Inge Brinkman

Language, Names, and War:

The Case of Angola

\section{Review Essays}

\section{Book Reviews}




\section{African Studies Review}

The Journal of the African Studies Association

\section{EDITORS}

Ralph Faulkingham, University of Massachusetts Amherst

Mitzi Goheen, Amherst College

Editorial Office:

African Studies Review

Department of Anthropology

240 Hicks Way

University of Massachusetts

Amherst MA 01003-9278

voice: $413 / 545-2065$

fax: $413 / 545-9494$

e-mail: asr@anthro.umass.edu

web site: http://www.umass.edu/anthro/asr

Office Manager: Angela Labrador

Copy Editor: Ella Kusnetz

Production Editor: Craig Malone

Manuscripts and correspondence about them should be sent to the editors. All manuscript submissions must conform to the requirements spelled out in the Style Guide that appears in the African Studies Review, volume 43 number 2 (September 2000), pp. 203-214. These requirements include, but are not limited to, the following features:

- Submit four copies, typed double-spaced, in a 12 point—or 10 characters per inch-font size.

- The text should not be longer than 25 pages

- Maps, tables, charts and other illustrations must be camera-ready.

- Citations within the text follow the author-date standard described in chapter 16 of the 14th edition of A Manual of Siyle (University of Chicago Press, 1993).

- Complete bibliographic references to the citations should be provided at the end of the essay in a section entitled "References."

- "Notes" should follow the References.

- Manuscripts will be sent to external peer reviewers; include a removable cover page giving essay title, author name and mailing address, fax number and e-mail address, if available; title should be repeated on the first page of text. Avoid any self-identification as author throughout the essay, so that peer reviewers will not be able to determine your identity.

- Include an abstract of not more than 100 words and a bio-sketch of the author of not more than 100 words.

- Include a signed statement that the essay has not been published and is not currently under consideration by other journals. The ASR will only consider unpublished manuscripts.

Book Review Editor: Eugenia Herbert, Mount Holyoke College

Editorial Office:

African-American and African Studies Program

Skinner Hall

Mount Holyoke College

South Hadley, MA 01075

voice: $413 / 538-2577$

fax: $413 / 538-2513$

email: asrbook@mtholyoke.edu or asrfilm@mtholyoke.edu

Books for review should be submitted to the book review editor. The African Studies Review accepts neither unsolicited book reviews nor requests by potential reviewers to review specitic books.

The editing of the African Studies Review is funded by Five Colleges, Inc., a consortium representing Amherst College, Hampshire College, Mount Holyoke College, Smith College, and the University of Massachusetts.

Cover design by Craig Malone. Cover image based on Bambara discharge-dyed mud cloth, from African Designs by Rebecca Jewell. A British Museum Pattem Book. London: British Museum Press, 1994, Plate 55. Used by permission. 


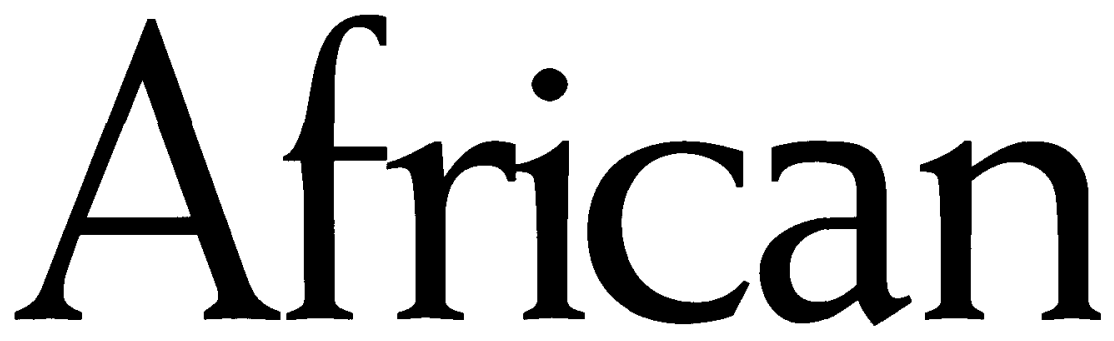

Studies Review

VOLUME 47, NUMBER 3

December 2004

African Studies Association

Rutgers, The State University of New Jersey

Douglass Campus

132 George Street

New Brunswick NJ 08901-1400 USA 


\section{NOTICE TO MEMBERS}

The United States Postal System does not fonward periodicals. We must receive written notification from you at least five weeks in advance of any change of mailing address. Failure to notify us of your correct mailing address will result in suspension of your membership mailings until we receive such notification. We can make address changes only when current dues are paid. Domestic claims for non-receipt of issues must be made to the Association's office within six months of publication (overseas claims, one year). Copies of the Review damaged in the mail will be replaced without charge.

The African Studies Review is published three times a year (April, September, and December) by the African Studies Association, Rutgers, The State University of New Jersey, Douglass Campus, 132 George St., New Brunswick, NJ 08901-1400, USA. Articles in the Review represent neither the views of the African Studies Association nor those of its officers; responsibility for opinions expressed and for the accuracy of facts published rests solely with the individual authors.

(C2004 African Studies Association

All rights reserved.

ISSN 0002-0206

No part of this publication may be reproduced or transmitted in any form or by any means, including photocopy, recording, or any information storage and retrieval system, without permission in writing from the publisher. Individual authors have the right to republish their articles in whole or in part without requesting permission from the Association; others desiring permission should apply to the Association. 


\section{African Studies Review}

VOLUME 47, NUMBER 3, DECEMBER 2004

\section{CONTENTS}

1 Kristen E. Cheney

"Village Life Is Better Than Town Life": Identity, Migration, and Development in the Lives of Ugandan Child Citizens

23 Jo Ellen Fair

"Me Do Wu," My Val: The Creation of Valentine's Day in Accra, Ghana

51 John C. McCall

Juju and Justice at the Movies: Vigilantes in Nigerian Popular Videos

69 Ayo Olukoyun

Media Accountability and Democracy in Nigeria, 1999-2003

91 Scott M. Youngstedt

Creating Modernities through Conversation Groups: The Everyday Worlds of Hausa Migrants in Niamey, Niger

119 Catherine Higgs

Zenzele: African Women's Self-Help Organizations in South Africa, 1927-1998

143 Inge Brinkman

Language, Names, and War: The Case of Angola

\section{REVIEW ESSAYS}

165 REVISITING FANON'S LIFE, TIMES, AND THOUGHT

Alice Cherki. Frantz Fanon, Portrait.

Nigel C. Gibson. Fanon: The Postcolonial Imagination.

David Macey. Frantz Fanon: A Biography.

(Guy Martin)

172 STUDYING GRIOTS: RECENT WORK IN MANDE STUDIES

Barbara G. Hoffman. Griots at War: Conflict, Conciliation, and Caste in Mande. Marloes Janson. The Best Hand Is the Hand That Always Gives: Griottes and Their Profession in Eastern Gambia.

Jan Jansen. Epopée, histoire, société: Le cas de Soundjata, Mali et Guinée.

Clemens Zobel. Das Gewicht der Rede: Kulturelle Reinterpretation, Geschichte und Vermittlung bei den Mande Westafrikas. 
Klaudia Dombrowski-Hahn. Nyagalen Mugan Tarawele: Une épopée bambara racontée par Bakoroba Koné.

Katrin Pfeiffer, ed. Mandinka Spoken Art: Folk-tales, Griot Accounts, and Songs.

Brahima Camara. Jägerliteratur in Manden: Gattungs- und Ubersetzungsprobleme afrikanischer Oralliteratur am Beispiel von Baala Jinbe Jakites Epos Bilakoro Mari (Teil1).

N'golo Konaté. Jägererzählungen der Bamanan: Transcription, Ubersetzung und Literarischer Kommentar.

Karim Traoré. Le jeu et le sérieux.

(Stephen Belcher)

187 THE NORDIC STATES AND LIBERATION IN SOUTHERN AFRICA: PART 2

Christopher M. Morgenstierne. Denmark and National Liberation in Southern Africa: A Flexible Response.

Tore L. Eriksen, ed. Norway and National Liberation in Southern Africa.

Tor Sellström, ed. Sweden and National Liberation in Southern Africa. Vol. 2: Solidarity and Assistance, 1970-1994.

(Richard Dale)

191 SOUTH AFRICA AT TEN: READINGS ON POSTAPARTHEID SOUTH AFRICA Fred Hendricks. Fault-Lines in South African Democracy: Continuing Crises of Inequality and Injustice.

Terry Bell, with Dumisa Buhle Ntsebeza. Unfinished Business: South Africa, Apartheid and Truth.

Sampie Terreblanche. A History of Inequality in South Africa 1652-2002.

Allister Sparks. Beyond the Miracle: Inside the New South Africa.

Hermann Gilliomee. The Afrikaners: Biography of A People.

(Mueni wa Muiu)

\section{BOOK REVIEWS}

\section{ANTHROPOLOGY AND SOCIOLOGY}

201 Debie LeBeau. Dealing with Disorder: Traditional and Western Medicine in Katatura (Namibia). (Catherine Collett)

\section{BIBLIOGRAPHIES \& DICTIONARIES}

203 Shelagh Willet, et al. The Khoe and San: An Annotated Bibliography. (Robert J. Gordon)

\section{ECONOMICS}

205 John James Quinn. The Road Oft Traveled: Development Policies and Majority State Ownership of Industry in Africa. (Alan Frishman)

206 Lucie Colvin Phillips and Diery Seck, eds. Fixing African Economies: Policy Research for Development. (Derrick K. Gondwe)

\section{GEOGRAPHY \& ENVIRONMENT}

208 Matthias Krings and Editha Platte, eds. Living with the Lake: Perspectives on History, Culture and Economy of Lake Chad. (Hamadou Adama)

209 Thomas J. Bassett and Donald Crummey, eds. African Savannas: Global Narratives and Local Knowledge of Environmental Change. (Monica M. van Beusekom) 
211 Christine J. Walley. Rough Waters: Nature and Development in an East African Marine Park. (Heidi Glaesel Frontani)

\section{HEALTH \& DISEASE}

213 Liz Walker, Graeme Reid, and Morna Cornell. Waiting to Happen: HIVIAIDS in South Africa-The Bigger Picture. (Jerome Teelucksingh)

\section{HISTORY}

215 Sylviane Diouf, ed. Fighting the Slave Trade: West African Strategies. (Emily S. Burrill)

216 Giacomo Macola. The Kingdom of Kazembe: History and Politics in North-Eastern Zambia and Katanga to 1950. (David Gordon)

218 Richard A. Olaniyan, ed. The Amalgamation and Its Enemies: An Interpretive History of Modern Nigeria. (Toyin Falola)

219 Nancy J. Jacobs. Environment, Power, and Injustice: A South African History. (Christopher J. Lee)

221 Toyin Falola and E. S. Atieno Odhiambo, eds. The Challenges of History and Leadership in Africa: The Essays of Bethwell Allan Ogot. (Edward A. Alpers)

222 Tim Couzens. Murder at Morija. (Richard Weisfelder)

224 Holly Elisabeth Hanson. Landed Obligation: The Practice of Power in Buganda. (Marcia Wright)

226 David Robinson. Muslim Societies in African History. (Heather J. Sharkey)

\section{LITERATURE AND ARTS}

228 Annie E. Coombes. Visual Culture and Public Memory in a Democratic South Africa: History after Apartheid. (Robin M. Chandler)

230 Isabel Hofmeyr. The Portable Bunyan: A Transnational History of The Pilgrim's Progress. (John Lemly)

231 Phanuel Akubueze Egejuru. Chinua Achebe: Pure and Simple, An Oral Biography. (Anne Serafin)

233 Josef Gugler. African Film: Re-Imagining a Continent. (Sheila Petty)

\section{MEMOIRS \& BIOGRAPHY}

235 Simon Zukas. Into Exile and Back. (Eugenia W. Herbert)

\section{POLITICS}

237 Padric Carmody. Tearing the Social Fabric: Neoliberalism, Deindustrialization, and the Crisis of Governance in Zimbabwe. (Connie Anthony)

238 Peter D. Little. Somalia: Economy without State. (Robert Press)

239 Donald Woods. Rainbow Nation Revisited: South Africa's Decade of Democracy. (Jerome Teelucksingh)

\section{WOMEN \& GENDER}

241 Amy Kaler. Running After Pills: Politics, Gender, and Contraception in Colonial Zimbabwe. (Luise White)

242 Lisa A. Lindsay and Stephan F. Miescher, eds. Men and Masculinities in Modern Africa. (Elizabeth Schmidt)

\section{BOOKS RECEIVED}

